\title{
Is candlestick continuation patterns applicable in Malaysian stock market?
}

\author{
Chee-Ling Chin ${ }^{1, *}$, Mohamad Jais ${ }^{1}$, Sophee Sulong Balia ${ }^{1}$, and Michael Tinggi ${ }^{1}$ \\ ${ }^{1}$ Department of Accounting and Finance, Universiti Malaysia Sarawak, Jalan Dato Mohd Musa, \\ 94300 Kota Samarahan, Sarawak, Malaysia
}

\begin{abstract}
Technical analysis is deemed to be an anathema to the modern finance theory as it contradicts with the efficient market hypothesis, typically the weak form market efficiency which forbids the utilization of past prices and trading volume data to predict future market movement. However, the technical indicator of candlestick trading strategy is widely applied by traders for short term investment. This study thus investigates on the predictive power of candlestick charting which concentrates on the application of continuation patterns in Malaysian stock market from 2000 to 2014. Skewness adjusted t-test is employed to test the statistical significance of candlesticks' profitability. After taking into account the transaction costs, sub-sample, and out-of-sample test, the findings show that only Falling Window pattern after a prevailing downtrend shows predictive power with bearish signals indicated significantly during the 5day holding period.
\end{abstract}

\section{Introduction}

The debating issue revolving around efficient market hypothesis and technical analysis has yet to be resolved until now. It is proposed that all sorts of readily available information including the public and private information have been fully incorporated into the prices of financial assets [1]. Hence, all three forms of market efficiency signify the impossibility to obtain abnormal returns in an efficient market despite any source of information received. Technical analysis on the other hand believes that market psychology can be traced by analyzing market trend through the aids of chart patterns and numerical calculation from past prices and trading volume data [2]. Technical indicators generate forecasted trading signals to assist traders in market timing. In particular, technical analysis is rejected by the weak form efficient market hypothesis which asserts that the use of historical information to forecast future market movement is useless.

The oldest known form of technical analysis is believed to be the Dow Theory which can be traced back to 1884 . Notwithstanding the continuous criticisms from the proponents of efficient market hypothesis, technical analysis is indeed widely applied by traders in the real time securities market. Positive evidence which supports the application of technical analysis are even been accumulated $[3,4,5,6,7]$. Recent findings from behavioral finance

*Corresponding author: cheelingchin26@gmail.com 
which show that investors do not always make decision rationally has added value to the practice of technical analysis method [8].

Among all the technical indicators, the Japanese candlestick charting is one of the most popular trading rules which is time-tested since 1700s in the Japanese futures market for commodity. Its popularity is even highlighted in the present time with the inclusion of candlestick charting technique in every real time technical service providers. In fact, candlestick charting technique acts as a leading indicator with its capability to provide trading signals earlier than other technical indicators. Besides, the flexibility and versatility of candlestick charting is underscored with its ability to function as a stand-alone technique or to combine with other Western technical indicators [9].

Mixed results are obtained for the studies on candlestick charting whereby negative evidence towards the predictability of candlesticks is gained on DJIA stocks [8], in the Japanese equity market [10] and for Brazilian stock market [11]. As the effectiveness of candlestick charting has been proven empirically in the Taiwan stock market $[12,13,14$, 15] while positive evidence is provided for the European stock market [16,17] and even in China [18], there is no known research in the past that has tested specifically on the predictability of continuation patterns. The significance of continuation patterns shall not be ignored even though it might not be as profitable as the reversal patterns. While reversal patterns typically allow traders to gain windfall from trend reversal signal with the concept of 'buy low and sell high', bullish continuation patterns on the other hand provide continuous buying signals which shall allow investors to hold their stocks longer before selling them at the optimal price to increase the probability of gaining higher profit while bearish continuation patterns function as persistent short-selling signals.

The controversy of candlestick trading strategy with the weak form market efficiency leads to a research issue which is worth study. In the context of Malaysian stock market, it was mentioned that the application of candlestick charting technique is deemed to be very suitable as it is observed to exhibit short term rallies followed by short term corrections with trading cycle ranges from three to fifteen days [19]. Therefore, this paper focuses solely on continuation patterns which have been overlooked by past researchers by examining the predictability of candlestick continuation patterns in Malaysian stock market from one day until fifteen days holding period.

\section{Candlestick charting}

Candlestick charting is formed from the opening, high, low, and closing price as shown in Figure 1. A white candlestick represents a bullish signal, whereas a black candlestick indicates a bearish signal. Candlestick patterns require a definite trend prior to the pattern to enable future market direction to be forecasted more accurately [9]. Continuation patterns are formed from a sequence of single line candlesticks. According to the Sakata Method, continuation patterns represent a time of rest in the market [20], which thus suggest that the prevailing trend shall persist. The common continuation patterns are identified from practitioner books $[9,19,20]$ and documented accordingly in Table 1.

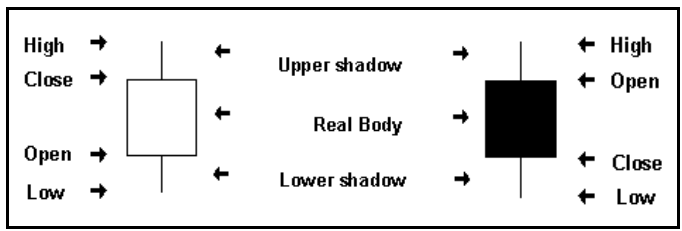

Figure 1. Single line candlesticks. 
Table 1. Continuation patterns.

\begin{tabular}{|c|c|c|c|}
\hline $\begin{array}{c}\text { Continuation } \\
\text { Pattern }\end{array}$ & $\begin{array}{l}\text { Prior } \\
\text { trend }\end{array}$ & Characteristics & Signal \\
\hline Falling Window & Downtrend & $\begin{array}{l}\text { The first and second day can be made up of any basic candles with } \\
\text { short or long line except for Four-Price Doji. A gap appears } \\
\text { between the first candle's low with the second candle's high. }\end{array}$ & Bearish \\
\hline Rising Window & Uptrend & $\begin{array}{l}\text { The first and second day can be made up of basic candles with } \\
\text { short or line except for Four-Price Doji. A gap appears between the } \\
\text { first candle's high with the second candle's low. }\end{array}$ & Bullish \\
\hline $\begin{array}{l}\text { Separating Lines- } \\
\mathbf{I} \mathbf{I}\end{array}$ & Downtrend & $\begin{array}{l}\text { The first day is a white candlestick. The second day is a black } \\
\text { candlestick with the same opening price as previous candlestick } \\
\text { and then closes lower. }\end{array}$ & Bearish \\
\hline Separating Lines+ & Uptrend & $\begin{array}{l}\text { The first day is a black candlestick. The second day is a white } \\
\text { candlestick with the same opening price as previous candlestick } \\
\text { and then closes higher. }\end{array}$ & Bullish \\
\hline On Neck & Downtrend & $\begin{array}{l}\text { The first day is a black candlestick. The second day is a white } \\
\text { candlestick which opens below the low of the previous day and } \\
\text { closes at or near the low of the first day's black candlestick. }\end{array}$ & Bearish \\
\hline In Neck & Downtrend & $\begin{array}{l}\text { The first day is a black candlestick. The second day is a white } \\
\text { candlestick which opens below the low of the previous day and } \\
\text { closes at or above the low of the first day's black candlestick. }\end{array}$ & Bearish \\
\hline Thrusting & Downtrend & $\begin{array}{l}\text { The first day is a black candlestick. The second day is a white } \\
\text { candlestick which opens at a lower price than the low of the first } \\
\text { day and closes within the body of the first day's body, but still } \\
\text { below the midpoint of the first day's black candlestick. }\end{array}$ & Bearish \\
\hline $\begin{array}{l}\text { Two Black } \\
\text { Gapping Candles } \\
\text { I I I }\end{array}$ & Downtrend & $\begin{array}{l}\text { The first day is a black candle with opening price gaps lower from } \\
\text { the previous candle. The second day is also a black candle with } \\
\text { opening price below prior candle's opening but higher than its low } \\
\text { and with closing price below the prior candle's closing. }\end{array}$ & Bearish \\
\hline $\begin{array}{l}\text { Side-by-Side } \\
\text { White Lines- } \\
\text { I I }\end{array}$ & Downtrend & $\begin{array}{l}\text { The first day is a long black candle. It is then follow by two } \\
\text { consecutive small white candles of similar size that gap below the } \\
\text { first day's black candle. }\end{array}$ & Bearish \\
\hline $\begin{array}{l}\text { Side-by-Side } \\
\text { White Lines+ } \\
\text { । I } 1 \text { ウ }\end{array}$ & Uptrend & $\begin{array}{l}\text { The first day is a white candle. It is then follow by two consecutive } \\
\text { small white candles of similar size that gap above the first day's } \\
\text { white candle. }\end{array}$ & Bullish \\
\hline
\end{tabular}

\section{Data and Methodology}

The main sample encompasses a total of 420 firms from 3 January 2000 to 30 December 2011 for in-sample analysis while the out-of-sample test utilizes a different set of data which are not reused in the in-sample data from 3 January 2012 to 31 December 2014 and comprises a total of 422 companies. The sub-sample test on the other hand only includes a total of 59 companies with average trading volume that exceeds one million unit shares from 2000 to 2007 after withdrawing the crisis period of 2008 to 2009 and post-crisis period from 2010 onwards.

The whole study is conducted based on three steps research design [15]. Firstly, all possible candlestick patterns that occur within the sample period is scanned and recognized with Candle Scanner software. Secondly, a three-day simple moving average ( $\left.\mathrm{SMA}_{3}\right)$ over six inequalities is employed to identify trends prior to the occurrence of patterns:

$$
\mathrm{MA}_{3}(\mathrm{t})=[\mathrm{P}(\mathrm{t}-2)+\mathrm{P}(\mathrm{t}-1)+\mathrm{P}(\mathrm{t})] / 3
$$


A set of inequalities is defined to help identifying market trends with acceptance of at most one violation of the inequalities. A downtrend is detected on day $t$ when:

$$
\mathrm{MA}_{3}(\mathrm{t}-6)>\mathrm{MA}_{3}(\mathrm{t}-5)>\ldots>\mathrm{MA}_{3}(\mathrm{t}-1)>\mathrm{MA}_{3}(\mathrm{t})
$$

Whereas an uptrend on day $t$ is defined as:

$$
\mathrm{MA}_{3}(\mathrm{t}-6)<\mathrm{MA}_{3}(\mathrm{t}-5)<\ldots<\mathrm{MA}_{3}(\mathrm{t}-1)<\mathrm{MA}_{3}(\mathrm{t})
$$

Thirdly, the stock returns is measured as the natural logarithm of the closing price on day $\mathrm{t}$ $+\mathrm{n}$ divided by the opening price on the day following a continuation pattern computed as:

$$
\text { Returns }=\ln \left(\mathrm{C}_{\mathrm{t}+\mathrm{n}} / \mathrm{O}_{\mathrm{t}+1}\right)
$$

,where $\mathrm{n}=$ number of holding period

As candlestick trading strategy is more suitable for short term investment, thus this study examines the raw returns of candlesticks rather than the abnormal ones. The stock returns is computed based on a buy-and-hold investment strategy and it is assumed that a trade is simulated at the opening price on the day following a continuation pattern and then sold at the end of the closing price after holding for a specific holding period. The profitability of continuation patterns is measured from 1-day until 15-day holding period to observe the predictability besides determining the effective holding period of continuation patterns in the context of Malaysian stock market. Binomial test is used to test the null hypothesis $\mathrm{H}_{0}: \mathrm{p}=0.5$ for the true returns rate of candlestick while skewness adjusted t-test is employed to test the null hypothesis $\mathrm{H}_{0}: \mu=0$ for the average returns with the formula stated below:

$$
\left.\mathrm{t}_{\mathrm{sa}}=\sqrt{\mathrm{n}}_{\mathrm{n}} \mathrm{s}+(1 / 3)(\gamma)\left(\mathrm{s}^{2}\right)+(1 / 6 \mathrm{n})(\gamma)\right]
$$

,where $\mathrm{s}=$ standard mean of returns and $\gamma=$ estimated skewness of returns.

A transaction cost of $1 \%$ is assumed in this study as stated under Bursa Malaysia which includes the brokerage fees, stamp duty, and clearing fees. The continuation patterns have correctly predict the direction of price movement if positive returns rate is obtained by bullish continuation patterns while bearish continuation patterns show negative returns rate. Meanwhile, a prevailing uptrend and downtrend is required for bullish and bearish continuation patterns respectively in order to confirm the predictive power of continuation patterns.

\section{Empirical Results}

\subsection{Candlestick statistics}

The statistics from Table 2 show that Falling Window is the only continuation pattern which has obtained significant bearish rate of more than $50 \%$ both before and after trend. It shows that Falling Window is more effective in reflecting bearish signals during the 10-day holding period as the highest bearish rate are recorded simultaneously at $51.50 \%$ before trend and at $52.30 \%$ after downtrend. It is also noticed that continuation patterns with trend identification are more effective in revealing correct signals as the true returns rate have increased following by a prevailing trend.

\subsection{Comparing bearish continuation patterns}

Table 3 shows that prior to trend, negative returns are attained more often during the 9-day, 10-day, and 11-day holding period while bearish signals tend to be reflected by bearish continuation patterns more frequent on 5-day holding period after a prevailing downtrend. Higher returns rate tend to indicate greater strength of signals. In overall, the bearish 
continuation patterns reflect stronger bearish signals after trend as compared to before trend as shown from higher magnitude of negative returns rate obtained after a prevailing downtrend. However, only the predictive power of Falling Window as bearish continuation pattern is found to exist after a prevailing downtrend. Bearish signals are shown significantly from negative returns obtained by Falling Window in both the in-sample and sub-sample test with both concentrating on 5-day holding period.

Table 2. True returns rate of continuation patterns before and after trend from 2000 to 2011 .

\begin{tabular}{|c|c|c|c|c|c|c|c|c|c|c|}
\hline \multirow{2}{*}{$\begin{array}{c}\text { Continuation } \\
\text { Patterns }\end{array}$} & \multirow[b]{2}{*}{ No. } & \multicolumn{4}{|c|}{ Before trend } & \multirow[b]{2}{*}{ No. } & \multicolumn{4}{|c|}{ After trend } \\
\hline & & 1 day & 5 day & 10 day & 15 day & & 1 day & 5 day & 10 day & 15 day \\
\hline Bearish Rate (\%): & & & & & & & & & & \\
\hline Falling Window & 16803 & $\begin{array}{c}39.43 \\
{[0.00]^{* * *}}\end{array}$ & $\begin{array}{l}50.54 \\
{[0.16]}\end{array}$ & $\begin{array}{c}51.50 \\
{[0.00]^{* * *}}\end{array}$ & $\begin{array}{l}50.49 \\
{[0.20]}\end{array}$ & 5088 & $\begin{array}{c}41.39 \\
{[0.00]^{* * *}}\end{array}$ & $\begin{array}{c}51.73 \\
{[0.02]^{* *}}\end{array}$ & $\begin{array}{c}52.30 \\
{[0.00]^{* * *}}\end{array}$ & $\begin{array}{l}49.98 \\
{[0.99]}\end{array}$ \\
\hline In Neck & 22 & $\begin{array}{l}45.45 \\
{[0.83]}\end{array}$ & $\begin{array}{r}59.09 \\
{[0.52]}\end{array}$ & $\begin{array}{l}59.09 \\
{[0.52]}\end{array}$ & $\begin{array}{r}59.09 \\
{[0.52]}\end{array}$ & 16 & $\begin{array}{l}50.00 \\
{[1.00]}\end{array}$ & $\begin{array}{l}02.50 \\
60.45]\end{array}$ & $\begin{array}{l}62.50 \\
{[0.45]}\end{array}$ & $\begin{array}{l}62.50 \\
{[0.45]}\end{array}$ \\
\hline On Neck & 276 & $\begin{array}{c}36.96 \\
{[0.00]^{* * *}}\end{array}$ & $\begin{array}{l}50.72 \\
{[0.86]}\end{array}$ & $\begin{array}{l}51.45 \\
{[0.67]}\end{array}$ & $\begin{array}{l}52.90 \\
{[0.37]}\end{array}$ & 148 & $\begin{array}{c}37.84 \\
{[0.00]^{* * *}}\end{array}$ & $\begin{array}{l}43.24 \\
{[0.12]}\end{array}$ & $\begin{array}{l}45.27 \\
{[0.28]}\end{array}$ & $\begin{array}{l}49.32 \\
{[0.94]}\end{array}$ \\
\hline Separating & 279 & 30.11 & 41.94 & 45.52 & 48.03 & 101 & 32.67 & 44.55 & 41.58 & 40.59 \\
\hline Thrusting & 340 & $\begin{array}{c}{[0.00]^{* * *}} \\
39.12 \\
{[0.00]^{* * *}}\end{array}$ & $\begin{array}{c}{[0.01]^{* * *}} \\
45.59 \\
{[0.12]}\end{array}$ & $\begin{array}{l}{[0.15]} \\
50.59 \\
{[0.87]}\end{array}$ & $\begin{array}{l}{[0.55]} \\
47.35 \\
{[0.36]}\end{array}$ & 196 & $\begin{array}{c}{[0.00]^{* * *}} \\
41.33 \\
{[0.02]^{* *}}\end{array}$ & $\begin{array}{c}{[0.32]} \\
41.84 \\
{[0.03]^{* *}}\end{array}$ & $\begin{array}{l}{[0.11]} \\
48.47 \\
{[0.72]}\end{array}$ & $\begin{array}{c}{[0.07]^{*}} \\
45.92 \\
{[0.28]}\end{array}$ \\
\hline $\begin{array}{l}\text { Two Black } \\
\text { Gapping Candles }\end{array}$ & 1642 & 45.25 & 51.40 & 51.46 & 50.00 & 846 & 43.85 & 48.94 & 50.83 & 49.53 \\
\hline & & {$[0.00]^{* * *}$} & {$[0.27]$} & {$[0.25]$} & {$[1.00]$} & & {$[0.00]^{* * *}$} & {$[0.56]$} & {$[0.65]$} & [0.81] \\
\hline $\begin{array}{l}\text { Bullish Rate (\%) } \\
\text { Rising Window }\end{array}$ & 13231 & $\begin{array}{c}35.63 \\
{[0.00]^{* * *}}\end{array}$ & $\begin{array}{c}42.80 \\
{[0.00]^{* * *}}\end{array}$ & $\begin{array}{c}41.93 \\
{[0.00]^{* * *}}\end{array}$ & $\begin{array}{c}40.77 \\
{[0.00]^{* * *}}\end{array}$ & 3123 & $\begin{array}{c}37.24 \\
{[0.00]^{* * *}}\end{array}$ & $\begin{array}{c}43.42 \\
{[0.00]^{* * *}}\end{array}$ & $\begin{array}{c}39.35 \\
{[0.00]^{* * *}}\end{array}$ & $\begin{array}{c}39.58 \\
{[0.00]^{* * *}}\end{array}$ \\
\hline $\begin{array}{l}\text { Separating } \\
\text { Lines }+\end{array}$ & 197 & $\begin{array}{c}37.06 \\
{[0.00]^{* * *}}\end{array}$ & $\begin{array}{l}51.78 \\
{[0.67]}\end{array}$ & $\begin{array}{l}45.18 \\
{[0.20]}\end{array}$ & $\begin{array}{l}46.70 \\
{[0.40]}\end{array}$ & 93 & $\begin{array}{l}41.94 \\
{[0.15]}\end{array}$ & $\begin{array}{l}53.76 \\
{[0.54]}\end{array}$ & $\begin{array}{l}43.01 \\
{[0.221}\end{array}$ & $\begin{array}{l}48.39 \\
{[0.83]}\end{array}$ \\
\hline
\end{tabular}

Bearish rate is obtained by dividing the number of bearish signals (Returns $<0$ ) by the total observed signals (No.) while bullish rate is derived by dividing the number of bullish signals (Returns $>0$ ) by the total observed signals (No.) and presented in percentage form. The p-values for Binomial test are provided in brackets. * Indicates statistical significance at $10 \%$ level, ** at $5 \%$ level, and $* * *$ at $1 \%$ level.

Table 3. Significant returns rate of bearish continuation patterns in various samples.

\begin{tabular}{|c|c|c|c|c|c|c|c|c|c|c|c|}
\hline \multirow[b]{3}{*}{$\begin{array}{c}\text { Bearish } \\
\text { Continuation } \\
\text { Patterns }\end{array}$} & \multicolumn{11}{|c|}{ Returns rate for different holding period (\%) } \\
\hline & \multicolumn{5}{|c|}{ Before trend } & \multicolumn{6}{|c|}{ After downtrend } \\
\hline & \multicolumn{2}{|c|}{$\begin{array}{c}\text { In-sample } \\
\text { (2000-2011) }\end{array}$} & \multicolumn{2}{|r|}{$\begin{array}{l}\text { Sub-sample } \\
(2000-2007)\end{array}$} & $\begin{array}{c}\text { Out-of- } \\
\text { sample } \\
\text { (2012- } \\
\text { 2014) }\end{array}$ & \multicolumn{2}{|c|}{$\begin{array}{l}\text { In-sample } \\
(2000-2011)\end{array}$} & \multicolumn{2}{|r|}{$\begin{array}{l}\text { Sub-sample } \\
(2000-2007)\end{array}$} & \multicolumn{2}{|c|}{$\begin{array}{c}\text { Out-of-sample } \\
(2012-2014)\end{array}$} \\
\hline & 4-day & $-3.16(0.07)^{*}$ & & & & 5 -day & $-4.10(0.09)^{*}$ & & & & \\
\hline In Neck & 5-day & $-3.34(0.06)^{*}$ & & & & 7-day & $-5.52(0.08)^{*}$ & & & & \\
\hline & 6-day & $-4.05(0.05)^{*}$ & & & & 9-day & $-6.83(0.03)^{* *}$ & & & & \\
\hline & 7-day & $-4.92(0.03)^{* *}$ & & & & 10-day & $-6.15(0.06)^{*}$ & & & & \\
\hline & 8-day & $-4.29(0.08)^{*}$ & & & & & & & & & \\
\hline & 9-day & $-5.48(0.03)^{* *}$ & & & & & & & & & \\
\hline & 10-day & $-5.50(0.03)^{* *}$ & & & & & & & & & \\
\hline \multirow{10}{*}{ On Neck } & 4-day & $-1.25(0.00)^{* * *}$ & & & & & & & & 12-day & $-3.45(0.08)^{*}$ \\
\hline & 5-day & $-1.24(0.00)^{* * *}$ & & & & & & & & 13-day & $-3.28(0.10)^{*}$ \\
\hline & 6-day & $-1.46(0.00)^{* * *}$ & & & & & & & & & \\
\hline & 9-day & $-1.20(0.02)^{* *}$ & & & & & & & & & \\
\hline & 10-day & $-1.33(0.01)^{* *}$ & & & & & & & & & \\
\hline & 11-day & $-1.38(0.01)^{* *}$ & & & & & & & & & \\
\hline & 12-day & $-1.17(0.05)^{* *}$ & & & & & & & & & \\
\hline & 13-day & $-1.20(0.06)^{*}$ & & & & & & & & & \\
\hline & 14-day & $-1.16(0.07)^{*}$ & & & & & & & & & \\
\hline & 15-day & $-1.30(0.04)^{* *}$ & & & & & & & & & \\
\hline & 4-day & $-1.05(0.00)^{* * *}$ & & & & & & & & & \\
\hline Two Black & 5-day & $-1.20(0.00)^{* * *}$ & & & & & & & & & \\
\hline Gapping & 7-day & $-1.18(0.00)^{* * *}$ & & & & & & & & & \\
\hline \multirow[t]{7}{*}{ Candles } & 8-day & $-1.24(0.00)^{* * *}$ & & & & & & & & & \\
\hline & 9-day & $-1.32(0.00)^{* * *}$ & & & & & & & & & \\
\hline & 10-day & $-1.40(0.00)^{* * *}$ & & & & & & & & & \\
\hline & 11-day & $-1.28(0.00)^{* * *}$ & & & & & & & & & \\
\hline & 12-day & $-1.15(0.00)^{* * *}$ & & & & & & & & & \\
\hline & 14-day & $-1.00(0.00)^{* * *}$ & & & & & & & & & \\
\hline & 15-day & $-1.00(0.00)^{* * *}$ & & & & & & & & & \\
\hline Falling & 9 9-day & $-1.00(0.00)^{* * *}$ & & & & 5-day & $-1.18(0.00)^{* * *}$ & 4-day & $-1.09(0.00)^{* * *}$ & & \\
\hline \multirow[t]{2}{*}{ Window } & 10 -day & $-1.04(0.00)^{* * *}$ & & & & & & 5-day & $-1.78(0.00)^{* * *}$ & & \\
\hline & 11-day & $-1.04(0.00)^{* * *}$ & & & & & & 7-day & $-1.12(0.00)^{* * *}$ & & \\
\hline \multirow{3}{*}{ Thrusting } & & & 11-day & $-2.23(0.07)^{*}$ & & & & 11-day & $-3.10(0.08)^{*}$ & & \\
\hline & & & 12-day & $-2.52(0.06)^{*}$ & & & & 12-day & $-3.31(0.07)^{*}$ & & \\
\hline & & & 15-day & $-3.14(0.04)^{* *}$ & & & & 15 -day & $-3.58(0.09)^{*}$ & & \\
\hline Separating & & & 7-day & $-2.61(0.08)^{*}$ & & & & & & & \\
\hline Lines- & & & 8-day & $-3.36(0.06)^{*}$ & & & & & & & \\
\hline $\begin{array}{l}\text { Side-by-Side } \\
\text { White Lines- }\end{array}$ & 3-day & $-5.50(0.08)^{*}$ & & & & & & & & & \\
\hline
\end{tabular}

The p-values of skewness adjusted t-test are provided in parentheses. * Indicates statistical significance at $10 \%$ level and $* *$ at $5 \%$ level. 


\subsection{Comparing bullish continuation patterns}

The predictive power of bullish continuation patterns are ambiguous as the results from robustness tests appear to be inconsistent with the in-sample result as shown from Table 4. Prior to trend identification, only the Bullish Side-by-Side White Lines reveals bullish signals with significant positive returns focusing on short holding period. After a prevailing uptrend, Bullish Separating Lines also portray bullish signals with positive returns rate during short holding period of one and two days but only for the sub-sample and out-ofsample test.

Table 4. Significant returns rate of bullish continuation patterns in various samples.

\begin{tabular}{|c|c|c|c|c|c|c|c|c|c|}
\hline \multirow{3}{*}{$\begin{array}{c}\text { Bullish } \\
\text { Continuation } \\
\text { Patterns }\end{array}$} & \multicolumn{9}{|c|}{ Returns rate for different holding period (\%) } \\
\hline & \multicolumn{4}{|c|}{ Before trend } & \multicolumn{5}{|c|}{ After uptrend } \\
\hline & & $\begin{array}{l}\text { 1-sample } \\
000-2011)\end{array}$ & $\begin{array}{l}\text { Sub-sample } \\
\text { (2000-2007) }\end{array}$ & $\begin{array}{c}\overline{\text { Out-of-sample }} \\
(2012-2014)\end{array}$ & $\begin{array}{c}\text { In-Sample } \\
(2000-2011)\end{array}$ & & $\begin{array}{l}\text { s-sample } \\
00-2007)\end{array}$ & & $\begin{array}{l}\text { of-sample } \\
12-2014)\end{array}$ \\
\hline Side-by-Side & 2-day & $1.51(0.04)^{* *}$ & & & & & & & \\
\hline White Lines+ & 6-day & $2.07(0.09)^{*}$ & & & & & & & \\
\hline $\begin{array}{l}\text { Separating } \\
\text { Lines+ }\end{array}$ & & & & & & 2-day & $1.51(0.09)^{*}$ & 1-day & $1.29(0.07)^{*}$ \\
\hline
\end{tabular}

The p-values of skewness adjusted t-test are provided in parentheses. ${ }^{*}$ Indicates statistical significance at $10 \%$ level and $* *$ at $5 \%$ level.

\section{Conclusion}

Continuation patterns suggest a persistence of current trend whereby bearish continuation patterns indicate continuous downtrend or bearish signal whereas bullish continuation patterns shall resume the prevailing uptrend or bullish signal. As limited number of continuation patterns are identified in Malaysian stock market, the results from this study show that Falling Window is the only continuation pattern which is found to be applicable after transaction costs. Following a prevailing downtrend, the predictive power of Falling Window as bearish continuation pattern is proven consistently on 5-day holding period with robustness test. Weak evidence is gained for effectiveness of candlestick charting technical indicator with only one continuation pattern proven to be significant, which thus suggest that Malaysia stock market is in weak form efficient market. As the current study is limited to Malaysian stock market for the application of continuation patterns, it is suggested that future research may focus on different securities market from other countries for comparison and further divide the sample according to characteristics of companies such as size and earnings ratio to examine the effectiveness of candlestick charting trading strategy.

Financial support from Universiti Malaysia Sarawak and Fundamental Research Grant Scheme [FRGS/SS05(04)/1149/2014(16)] are gratefully acknowledged.

\section{References}

1. E. Fama, Efficient capital markets: A review of theory and empirical work. Journal of Finance, 25, 383-417 (1970)

2. J. J. Murphy, Technical analysis of the financial markets: A comprehensive guide to trading methods and applications. New York, Penguin Putnam Inc (1999)

3. J. L. Treynor, R. Ferguson, In defense of technical analysis. Journal of Finance, 40, 757-773 (1985)

4. W. Brock, J. Lakonishok, B. LeBaron, Simple technical trading rules and the stochastic properties of stock returns. Journal of Finance, 47, 1731-1764 (1992)

5. A. W. Lo, H. Mamaysky, J. Wang, Foundations of technical analysis: Computational algorithms, statistical inference, and empirical implementation. Journal of Finance, 55, 1705-1765 (2000) 
6. P. Shen, Market timing strategies that worked. Journal of Portfolio Management, 29, 57-68 (2003)

7. C. J. Neely, D. E. Rapach, J. Tu, G. Zhou, Forecasting the equity premium: The role of technical analysis. Journal of Management Science, 60,7, 1772-1791 (2011)

8. B. R. Marshall, M. R. Young, L. C. Rose, Candlestick technical trading strategies: Can they create value for investors? Journal of Banking \& Finance, 30, 2303-2323 (2006)

9. S. Nison, Japanese candlestick charting techniques. New York, New York Institute of Finance (1991)

10. B. R. Marshall, M. R. Young, R. Cahan, Are candlestick technical trading strategies profitable in the Japanese equity market? Review of Quantitative Finance and Accounting, 31, 191-207 (2008)

11. H. A. Prado, E. Ferneda, L. C. R. Morais, A. J. B. Luiz, E. Matsura, On the effectiveness of candlestick chart analysis for the Brazilian stock market. Procedia Computer Science, 22, 1136-1145 (2013)

12. Y. Shiu, T. Lu, Pinpoint and synergistic trading strategies of candlesticks. International Journal of Economics and Finance, 3,1, 234-244 (2011)

13. T. Lu, Y. Shiu, Tests for two-day candlestick patterns in the emerging equity market of Taiwan. Emerging Markets Finance and Trade, 48, 41-57 (2012)

14. T. Lu, Y. Shiu, T. Liu, Profitable candlestick trading strategies: The evidence from a new perspective. Review of Financial Economics, 21,2, 63-68 (2012)

15. T. Lu, The profitability of candlestick charting in the Taiwan stock market. PacificBasin Finance Journal, 26, 65-78 (2014)

16. G. Caginalp, H. Laurent, The predictive power of price patterns. Applied Mathematical Finance, 5, 181-205 (1998)

17. T. Lu, J. Chen, Candlestick charting in European stock markets. The Finsia Journal of Applied Finance, 2, 20-25 (2013)

18. M. Zhu, S. Atri, E. Yegen, Are candlestick trading strategies effective in certain stocks with distinct features? Pacific-Basin Finance Journal, 37, 116-127 (2016)

19. F. K. H. Tam, Investing in KLSE stocks and futures with Japanese candlestick charting techniques. Selangor Darul Ehsan, Malaysia, Pelanduk Publications (2001)

20. G. Morris, Candlestick charting explained: Timeless techniques for trading and futures (3rd ed.). New York, McGraw-Hill (2006) 